\title{
The Relationship between Selenium and T3 in Selenium Supplemented and Nonsupplemented Ewes and Their Lambs
}

\author{
Abd Elghany Hefnawy, ${ }^{1}$ Seham Youssef, ${ }^{1}$ P. Villalobos Aguilera, ${ }^{2}$ \\ C. Valverde Rodríguez, ${ }^{2}$ and J. L. Tórtora Pérez ${ }^{3}$ \\ ${ }^{1}$ Faculty of Veterinary Medicine, Benha University, Moshtohor 13736, Egypt \\ ${ }^{2}$ Instituto de Neurobiología, Universidad Nacional Autónoma de México, Mexico \\ ${ }^{3}$ Facultad de Estudios Superiores Cuautitlán, Universidad Nacional Autónoma de México, \\ Km. 2.5 Carretera Cuautitlán-Teoloyucan, 54714 Cuautitlán Izcalli, MEX, Mexico
}

Correspondence should be addressed to Abd Elghany Hefnawy; abdelghani72@yahoo.com

Received 19 September 2013; Revised 1 January 2014; Accepted 2 January 2014; Published 10 February 2014

Academic Editor: Philip H. Kass

Copyright (C) 2014 Abd Elghany Hefnawy et al. This is an open access article distributed under the Creative Commons Attribution License, which permits unrestricted use, distribution, and reproduction in any medium, provided the original work is properly cited.

\begin{abstract}
Twenty pregnant ewes were selected and classified into two groups. The first group received subcutaneous selenium supplementation $(0.1 \mathrm{mg}$ of sodium selenite $/ \mathrm{kg} \mathrm{BW})$ at the 8 th and 5 th weeks before birth and 1st week after birth while the other was control group without selenium injection. Maternal plasma and serum samples were collected weekly from the 8th week before birth until the 8 th week after birth and milk samples were taken from ewes weekly, while plasma and serum samples were collected at 48 hours, 1st, 2nd, 3rd, 5th, and 8th weeks after birth from the newborn lambs. Results demonstrated significant positive relationship between maternal plasma selenium and serum T3 in supplemented and control ewes $(r=0.69$ to $0.72, P<0.05)$. There was significant $(P<0.001)$ increase in T3 in supplemented ewes and their lambs until the 8th week after birth. There was positive relationship between milk, selenium concentration, and serum T3 in the newborn lambs of the supplemented group $(r=0.84, P<0.01)$, while the relationship was negative in the control one $(r=-0.89, P<0.01)$. Muscular and thyroid pathological changes were independent of selenium supplementation. Selenium supplementation was important for maintaining T3 in ewes and newborn lambs until the 8th week after birth.
\end{abstract}

\section{Introduction}

Recognized as an essential trace element in 1957 [1], selenium (Se) is a key component of the so-called selenoproteins and plays a critical role in various aspects of human and animal health $[2,3]$. In the thyroid gland, Se is associated with the activity of redox-protective peroxidases which prevent thyroid cell from oxidative damage during the process of hormonogenesis $[4,5]$. Furthermore, Se is also necessary in the synthesis of iodothyronine deiodinases (D), the family of selenoenzymes which are critical for the control of thyroid hormone $(\mathrm{TH})$ action at the cellular level. Deiodinases type 1 and 2 (D1 and D2) catalyze the activation of tetraiodothyronine $\left(\mathrm{T}_{4}\right)$ to triiodothyronine $\left(\mathrm{T}_{3}\right)$ and $\mathrm{D} 1$ and $\mathrm{D} 3$ inactivate $T_{4}$ to reverse $T_{3}$ or $T_{3}$ to $T_{2}[2,6,7]$. Se deficiency induces a significant reduction in $\mathrm{T}_{3}$ with the corresponding increase in
$\mathrm{T}_{4}$ and a reduction in the activity of hepatic $\mathrm{D} 1[2,8-13]$. On the other hand and as recently reviewed [3], several studies have shown that supplemental sodium selenite and sodium selenate by oral or parenteral administration forestall the clinical signs of Se deficiency and animal losses in ruminant and nonruminant species $[14,15]$. Transfer of nutrients and Se from the dam to the offspring occurs via two pathways, placental transfer and colostrum-milk ingestion. The amount of nutrients transferred to offspring depends on the maternal nutrient status and the efficiency of the transplacental and mammary transport mechanism. Se is efficiently transferred via the placenta to the fetus, even in situations of low maternal concentration of the element $[16,17]$. The objective of this study is to assess the effect of pre- and postpartum Se supplementation on thyroid and Se homeostasis in ewes and their newborn lambs. 


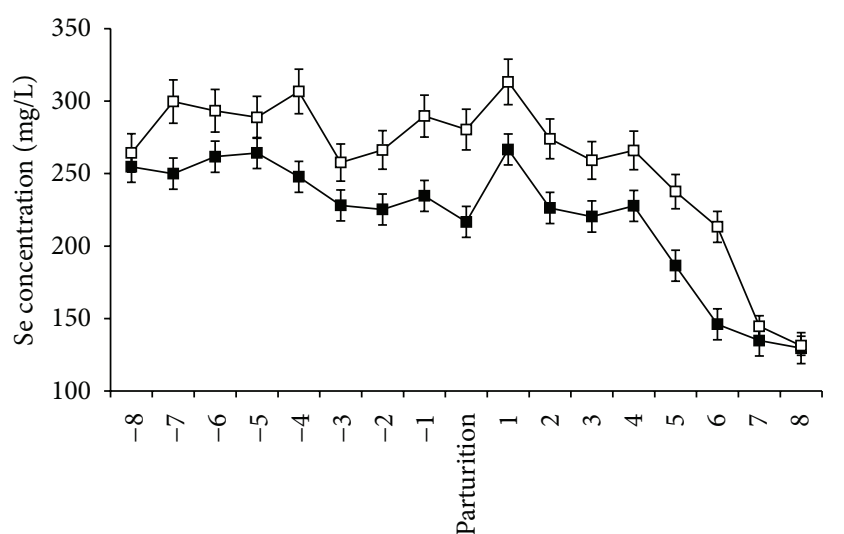

Weeks related to parturition

$\rightarrow$ - Control group

$\rightarrow-$ Supplemented group

Figure 1: Plasma Se concentrations (mean \pm SEM) of Se supplemented and control ewes.

\section{Materials and Methods}

Twenty primiparous pregnant Pelibuey ewes were selected after ultrasound examination approximately at 90 days of pregnancy. The ewes were 1.5-2 years of age with an average body weight of $41.09 \pm 0.8 \mathrm{~kg}$. These ewes were divided into two groups, the 1st group $(n=10)$ were supplemented with subcutaneous injection (SC) of sodium selenite, $0.1 \mathrm{mg} / \mathrm{kg}$ BW, at the 8 th and 5 th weeks prepartum and at the 1st week postpartum, while the control group $(n=10)$ did not receive Se. Deficiency of blood Se level in the experimental ewes was $250 \mathrm{ppm}$ (Figure 1). Ewes had a high corporal condition (average body weight was $41.09 \pm 0.8 \mathrm{~kg}$ ). Both groups feed a diet elaborated with alfalfa, corn, and soybean with a mineral salt containing 0.5 iodine $\mathrm{mg} / \mathrm{kg} \mathrm{DM}$ and without Se (Table 1) and water ad libitum. The Se concentration in the diet was 0.22 and $0.23 \mathrm{ppm}$ during pregnancy and lactation, respectively.

Blood samples from gestated ewes were collected weekly from the 8 th week prepartum until the 8 th week postpartum. Postpartum samples from newborns were obtained at $48 \mathrm{~h}$ and at the 1st, 2nd, 3rd, 5th, and 8th weeks and milk samples were collected weekly. In both ewes and newborns, blood was collected in the morning (8:00 am) by jugular vein puncture using vacutainer tubes and divided into two portions. The first portion was taken on EDTA as anticoagulant for obtaining of plasma while the second portion was left to clot at room temperature for about 20 minutes and then centrifuged at 3000 r.p.m. for 15 minutes; the supernatant serum samples were drown and kept frozen $\left(-80^{\circ} \mathrm{C}\right)$ until analyzed. Milk $(2 \mathrm{~mL})$ was collected in the same schedule of the blood samples. As previously described, Se was measured in the plasma, milk, and diet by atomic absorption spectrophotometer [17], while serum $\mathrm{T}_{3}$ was measured by radioimmunoassay [18]. At the end of the experiment, ewes and lambs were sent to slaughterhouse and part of the thyroid gland, the diaphragmatic muscle, and the myocardium were
TABle 1: Diet supplied to ewes during experimental period (kg/head/day).

\begin{tabular}{lcc}
\hline Item & Gestation & Lactation \\
\hline Roughage & 0.4 & 0.5 \\
Alfalfa & 1.3 & 0.7 \\
Soy-bean & 0.2 & 0.4 \\
Ground corn & 0.3 & 0.9 \\
Mineral salt & 0.006 & 0.007 \\
Water & Ad libitum & Ad libitum \\
Crude protein & $15 \%$ & $15 \%$ \\
Energy (Mcal $/ \mathrm{kg})$ & 2.3 & 2.7 \\
\hline
\end{tabular}

collected in $10 \%$ buffered formalin solution and processed for histopathological evaluation to obtain paraffin cuts as routine.

\section{Statistical Analysis}

The obtained results from the experiments were expressed as mean \pm SEM and were analyzed by analysis of variance (ANOVA) for repeated measures with means tested for significance by Duncan's multiple range tests. The correlation between the obtained results was tested with a Pearson correlation test. Differences were declared significant at $P<$ 0.05 .

\section{Results}

One ewe from the control group aborted and was eliminated. There was significant $(P<0.05)$ increase in the plasma Se concentrations in Se supplemented ewes (Figure 1) and their lambs $(P<0.01)$ (Figure 2$)$ than that of the nonsupplemented group. Compared to control animals and during the entire study, circulating levels of $\mathrm{T}_{3}$ were higher $(P<0.001)$ in Se supplemented ewes. Moreover, these differences in serum hormone concentrations became more evident during lactation where $\mathrm{T}_{3}$ mean values for supplemented and nonsupplemented ewes were $200 \pm 60 \mathrm{ng} / \mathrm{dL}$ and $150 \pm 35 \mathrm{ng} / \mathrm{dL}$, respectively (Figure 3 ). Similarly, serum $\mathrm{T}_{3}$ in lambs born from Se supplemented ewes was higher $(P<0.01)$ than in those born from control ewes (Figure 4 ). This difference between both groups of newborns was maintained up to the 8 th week of the age. There was a positive correlation between maternal plasma Se concentration and serum $\mathrm{T}_{3}$ in both supplemented and nonsupplemented ewes $(r=0.69$ to 0.72 , $P<0.05)$. In contrast, serum $\mathrm{T}_{3}$ and milk Se concentrations were positively correlated in the supplemented ewes $(r=$ $0.60, P<0.05)$, while this correlation was negative in the control group $(r=-0.80, P<0.05)$. A similar pattern between serum $\mathrm{T}_{3}$ and milk Se concentration was observed in newborns. The correlation was positive in the lambs born from Se supplemented ewes $(P<0.01, r=0.84)$ and negative in the lambs born from the control group $(P<0.01, r=$ $-0.89)$. 


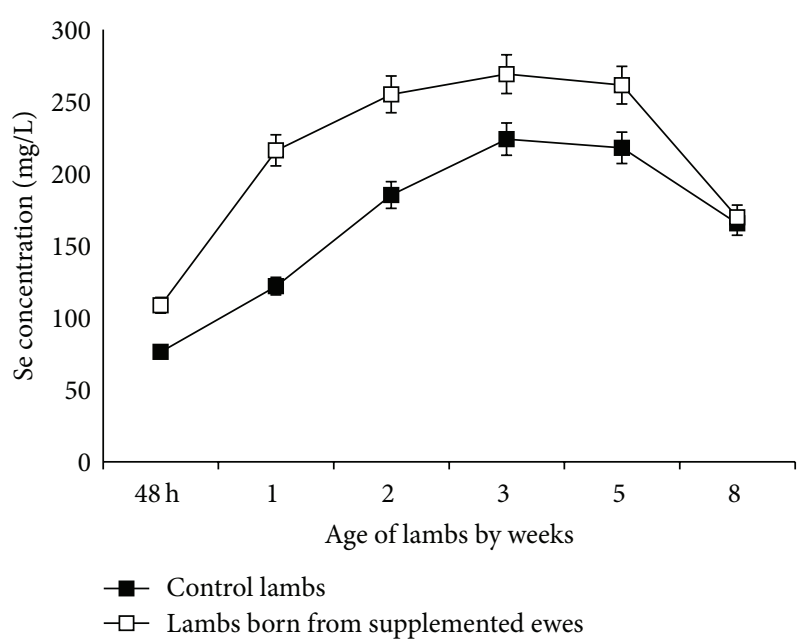

Figure 2: Plasma Se concentrations (mean \pm SEM) of newborn lambs from Se supplemented and control ewes.

The diaphragm and myocardium histopathological studies revealed that muscular nucleus proliferation and mononuclear macrophages infiltrate in association with swollen muscular fibers (Figure 5). However, the most conspicuous alterations were observed in the thyroid gland of ewes. There were notorious differences in size, follicular content aspect, staining homogeneous or vacuolated, and empty follicles. Large and dilated follicles, macrofollicles, with flat epithelial cells (goiter aspect) coexisted with much smaller follicles that presented columnar epithelium (embryonic aspect). The most relevant changes included folded follicular epithelial structures, with villous aspect and irregular follicular lumen. Double epithelial layer was observed in some follicles coexisting with collapsed follicular structures observed as cords and nodular columnar epithelial structures. Pyknotic nucleuses were observed in epithelial and fusiform interstitial cells (Figures 6, 7, 8, and 9). Lambs thyroid glands were considered normal; some differences on follicular size were observed only. Histological muscular and thyroid changes were independent of treatment.

\section{Discussion}

Besides agreeing with previous studies showing the important deficit in vegetal and animal selenium levels in most regions of México [19], present results add further support that Se supplementation is critical in these conditions to sustain ruminants' production and thyroid function, similar to other animals and humans $[2,4-8,13,19-21]$. On the other hand, iodine deficiency and goitrogenic factors have been reported in humans in focalized areas of México only [22, 23]. Animal deficiency has not been reported in México.

According to studies in bovines and ewes $[8,12,13$, 21], present results demonstrate clearly the importance of Se supplementation to maintain $\mathrm{Se}$ and $\mathrm{T}_{3}$ homeostasis in both pregnant ewes and their offspring. Rock et al. [13] demonstrated this condition in pregnant ewes but $\mathrm{T}_{3}$ only presented a tendency to have higher levels in their lambs.

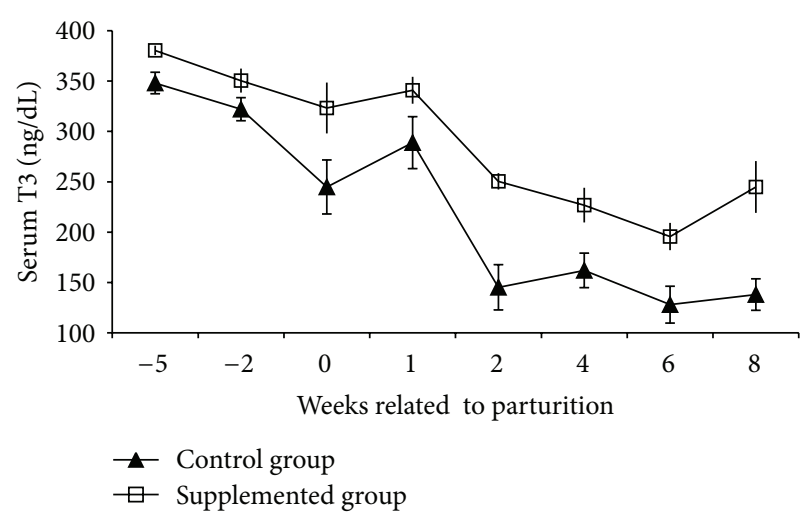

FIgURE 3: Serum T3 concentrations (mean \pm SEM) of Se supplemented and control ewes.

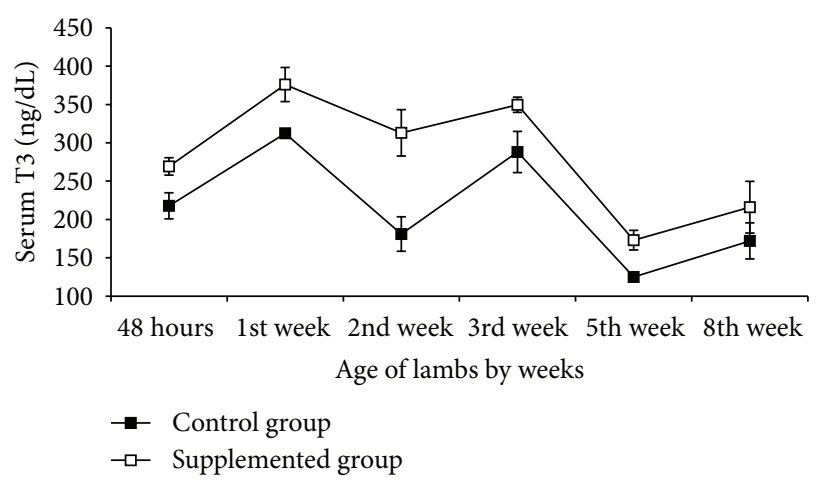

FIGURE 4: Serum T3 concentration (mean \pm SEM) of newborn lambs from Se supplemented and control ewes.

Differences between this work and our results may be due to original levels of Se in ewes, the source of Se supplementation, breed and age of experimental ewes, and in the fact that they evaluated $12 \mathrm{~h}$ pospartum experimental lambs only. Rock et al. [13] used crossbreed wool sheep (Rambouillet $\times$ Polypay); in contrast, in this work, crossbreed hair ewes (Pelibuey $\times$ Katahdin) were used; this difference may affect Se and $\mathrm{T}_{3}$ thermometabolism requirements.

Our data show that lambs that were born from Sesupplemented ewes and took naturally colostrum and milk from their dams had serum $\mathrm{T}_{3}$ significantly higher than those from nonsupplemented ewes. Moreover, serum $\mathrm{T}_{3}$, plasma, and milk Se concentration were positively correlated in supplemented and nonsupplemented ewes as well as in lambs that were born from supplemented ewes. In contrast, this correlation was negative in newborns from nonsupplemented ewes. These data strongly suggest that nonsupplemented ewes reduce Se transfer to milk and to the offspring, diverting Se reserves primarily to maintain their own Se and thyroid homeostasis. These results agree with those of other researchers $[8,11]$ and confirm the hierarchical importance of selenoenzyme synthesis in the maternal organism $[5,24,25]$.

High mortality rates in newborns lambs from nonsupplemented ewes than in those born from supplemented ewes have been reported [26]. In this context, hypothermia is one 


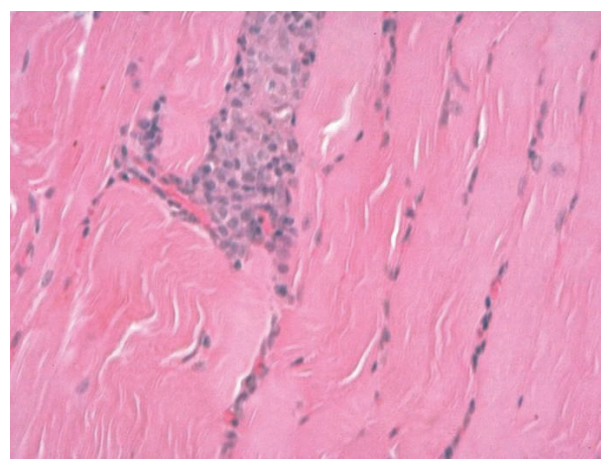

(a)

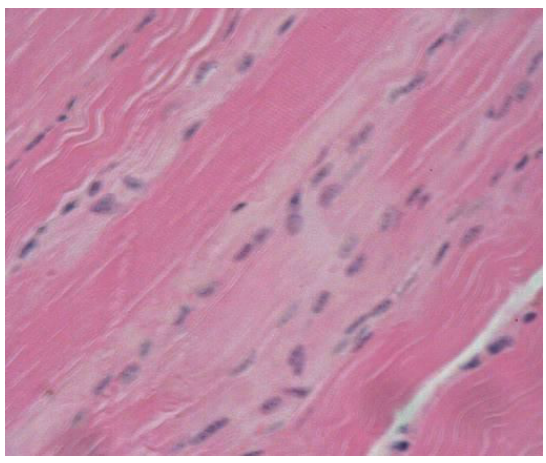

(b)

Figure 5: Muscular dystrophy. (a) Mononuclear infiltration replaced a damage muscular fiber, H\&E, 160x. (b) Muscular nucleus proliferation in damage pale fibers in ewes. $\mathrm{H} \& \mathrm{E}, 80 \mathrm{x}$.

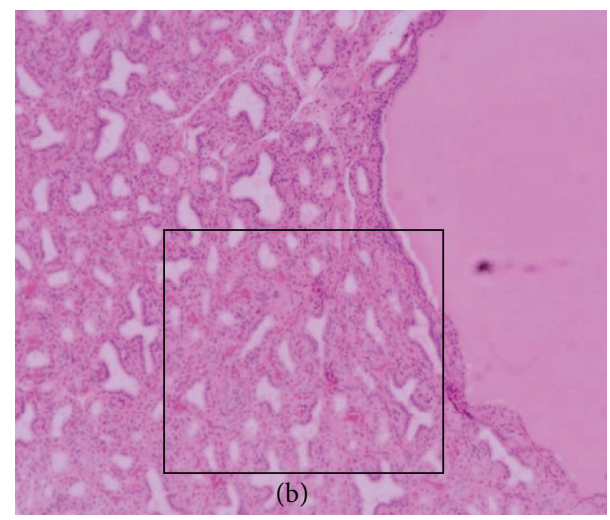

(a)

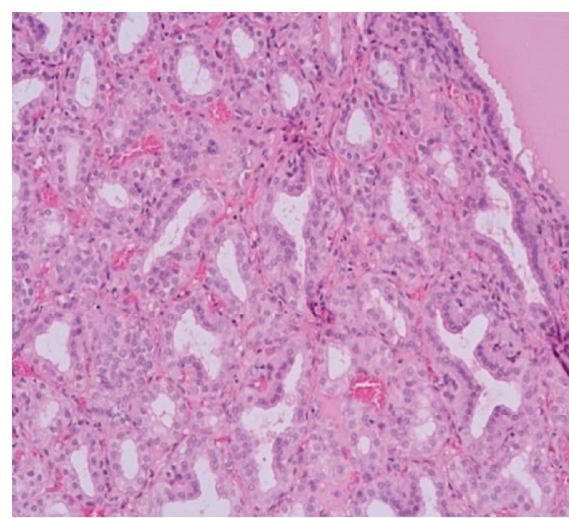

(b)

FIgURE 6: Thyroid sections. (a) A macrofollicular structure contrast with collapsed and folded empty follicular structures. H\&E, 80x. (b) Detail of collapsed and folded empty follicular structures in ewes, H\&E, 160x.

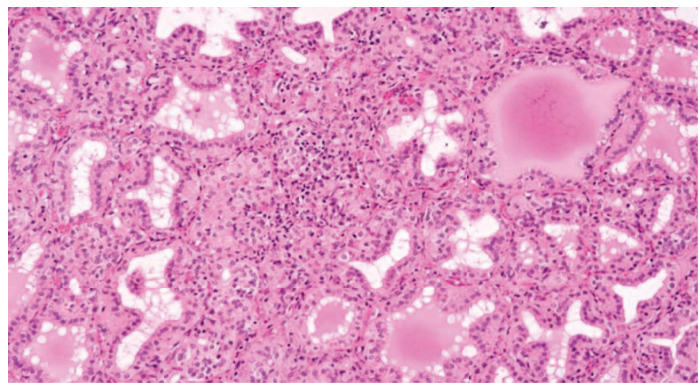

FIGURE 7: Thyroid sections folded, empty, and vacuolated content follicular structures and a disrupted follicular zone, with pyknotic nucleus in ewes, H\&E 160x.

of the major causes of newborn lamb mortality and that $\mathrm{T}_{3}$ is essential to the synthesis of uncoupling protein necessary for the thermogenic activity of brown adipose tissue $[27,28]$. Nevertheless Rock et al. [13] did not demonstrate effects of Se supplementation on thermometabolism of experimental lambs. This data support the proposal of maintaining ewes Se supplementation throughout the lactation period. Significant

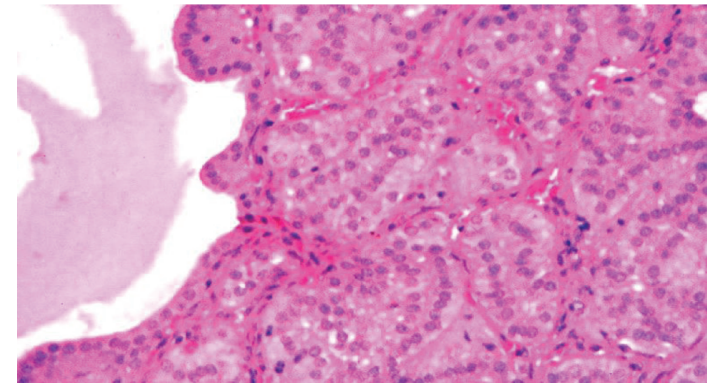

FIGURE 8: Thyroid sections big follicular structure with a folded wall, collapsed follicles, and pyknotic interstitial nucleus in ewes, $\mathrm{H} \& \mathrm{E}$, 380x.

increase in T3 in ewes and lambs of Se supplemented group against the control one may be attributed to increase in the activity of Se dependent deiodinase enzymes [29].

The significant positive relationship between maternal plasma Se and serum $\mathrm{T}_{3}$ concentrations and the significant decrease in $\mathrm{T}_{3}$ levels towards parturition in the control group indicates the importance of maternal Se supplementation to 


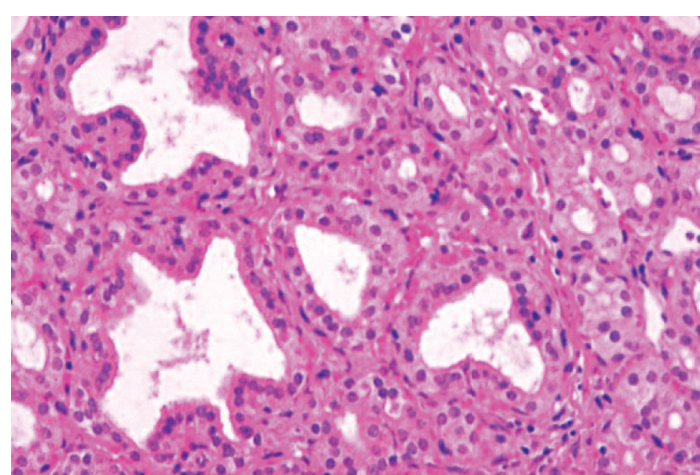

FIGURE 9: Thyroid sections folded empty follicular structures associated with embryonic aspect rounded follicles. Pyknotic interstitial and follicular nucleus are present in ewes, H\&E, 380x.

maintain Se and $\mathrm{T}_{3}$ homeostasis in pregnant ewes. These results agree with Rock et al. [13] and Rowntree et al. [21] observations in cows as well as with the well-known transplacental Se transference $[17,30]$ and its beneficial effects throughout colostrum and milk [20,31].

According to previous studies in ewes and cows [12, 13], lambs born from Se supplemented ewes had serum $\mathrm{T}_{3}$ significantly higher than those born from nonsupplemented ewes. At the 8th week postpartum, no significant differences between lambs born from Se supplemented and control groups were observed, probably associated with decrease in milk Se concentration at this moment [31]. Head et al. [32] found that T3 in newborn lambs increased since the 4th day postpartum and then decreased on the 84th day and then began to rise. In this work, T3 level began to decrease on the 5th week postpartum and rose again on the 8th week. These findings suggest that $\mathrm{T} 3$ levels were elevated during lambs active growth associated with high milk production of the dams and then decreased and began to rise again when lamb initiated forage intake. This enforces the importance of lambs Se supplementation before the 8th week to maintain plasma Se level and consequently T3 activity.

Calves born from Se supplemented dams had higher levels of T3 than those born from nonsupplemented [12]. These results agree with the ones of the present study. Nevertheless, Rowntree et al. [21] found that maternal Se supplementation only until calving did not influence neonatal calf thyroid hormone concentrations.

No relationships between muscular and thyroid histopathological changes with Se supplementation were observed. Probably lesions occurred in a previous experimental Se deficiency period and persist as a scar; nevertheless, ewes were supplemented. Early reproductive activity and twin gestation in the ewes used for the experiment may cause Se deficiency condition and serious lesions described. Short supplementation period before animals were sacrificed probably was insufficient to lesions resolution. Observed lesions were similar to experimental animals previously described with Se and iodine deficiencies $[5,33]$ and suggested a combination between degenerative necrotic lesions and hypertrophic compensatory changes. These severe thyroid pathological changes have not been previously described in ewes or other domestic animals. Human studies in México did not consider Se deficiency as a goitrogenic factor $[22,23]$. The usage of sheep as a model should be considered as Se status of experimental animals to evaluate thyroid function $[34,35]$.

\section{Conclusion}

Pre- and pospartum Se supplementation is essential to maintain $\mathrm{Se}$ and $\mathrm{T}_{3}$ homeostasis during late pregnancy and postpartum period in ewes and their lambs until the 8th week of age.

\section{Conflict of Interests}

The authors declare that there is no conflict of interests regarding the publication of this paper.

\section{Acknowledgment}

This project was financed by PAPIIT-UNAM: IN209906-2.

\section{References}

[1] K. Schwarz and C. M. Foltz, "Selenium as an integral part of factor 3 against dietary necrotic liver degeneration. 1951," Nutrition, vol. 15, no. 3, p. 255, 1999.

[2] J. Köhrle, F. Jakob, B. Contempré, and J. E. Dumont, "Selenium, the thyroid, and the endocrine system," Endocrine Reviews, vol. 26, pp. 944-984, 2007.

[3] A. E. Hefnawy and J. L. Tórtora-Pérez, "The importance of selenium and the effects of its deficiency in animal health," Small Ruminant Research, vol. 89, pp. 185-1892, 2010.

[4] R. Gärtner, B. C. H. Gasnier, J. W. Dietrich, B. Krebs, and M. W. A. Angstwurm, "Selenium supplementation in patients with autoimmune thyroiditis decreases thyroid peroxidase antibodies concentrations," Journal of Clinical Endocrinology and Metabolism, vol. 87, no. 4, pp. 1687-1691, 2002.

[5] L. Schomburg, C. Riese, M. Michaelis et al., "Synthesis and metabolism of thyroid hormones is preferentially maintained in selenium-deficient transgenic mice," Endocrinology, vol. 147, no. 3, pp. 1306-1313, 2006.

[6] G. J. Beckett, S. E. Beddows, P. C. Morrice, F. Nicol, and J. R. Arthur, "Inhibition of hepatic deiodination of thyroxine is caused by selenium deficiency in rats," Biochemical Journal, vol. 248, no. 2, pp. 443-447, 1987.

[7] G. J. Beckett and J. R. Arthur, "Selenium and endocrine systems," Journal of Endocrinology, vol. 184, no. 3, pp. 455-465, 2005.

[8] J. R. Arthur, P. C. Morrice, and G. J. Beckett, "Thyroid hormone concentrations in selenium deficient and selenium sufficient cattle," Research in Veterinary Science, vol. 45, no. 1, pp. 122-123, 1988.

[9] G. J. Beckett, F. Nicol, P. W. H. Rae, S. Beech, Y. Guo, and J. R. Arthur, "Effects of combined iodine and selenium deficiency on thyroid hormone metabolism in rats," The American Journal of Clinical Nutrition, vol. 57, no. 2, supplement, pp. 2405-2435, 1993. 
[10] K. M. Thompson, H. Haibach, and R. A. Sunde, "Growth and plasma triiodothyronine concentrations are modified by selenium deficiency and repletion in second-generation seleniumdeficient rats," Journal of Nutrition, vol. 125, no. 4, pp. 864-873, 1995.

[11] J. J. Wichtel, A. L. Craigie, D. A. Freeman, H. Varela-Alvarez, and N. B. Williamson, "Effect of selenium and iodine supplementation on growth rate and on thyroid and somatotropic function in dairy calves at pasture," Journal of Dairy Science, vol. 79, no. 10, pp. 1865-1872, 1996.

[12] F. T. Awadeh, R. L. Kincaid, and K. A. Johnson, "Effect of level and source of dietary selenium on concentrations of thyroid hormones and immunoglobulins in beef cows and calves," Journal of Animal Science, vol. 76, no. 4, pp. 1204-1215, 1998.

[13] M. J. Rock, R. L. Kincaid, and G. E. Carstens, "Effects of prenatal source and level of dietary selenium on passive immunity and thermometabolism of newborn lambs," Small Ruminant Research, vol. 40, no. 2, pp. 129-138, 2001.

[14] C. B. Ammerman and S. M. Miller, "Selenium in ruminant nutrition: a review," Journal of Dairy Science, vol. 58, no. 10, pp. 1561-1577, 1975.

[15] M. Hidiroglou, J. Proulx, and J. Jolette, "Effect of intraruminally administered, selenium soluble-glass boluses on selenium status in cows and their calves," Journal of Animal Science, vol. 65, no. 3, pp. 815-820, 1987.

[16] L. D. Koller, G. A. Whitbeck, and P. J. South, "Transplacental transfer and colostral concentrations of selenium in beef cattle," The American Journal of Veterinary Research, vol. 45, no. 12, pp. 2507-2510, 1984.

[17] A. E. Hefnawy, R. López-Arellano, A. Revilla-Vázquez, E. Ramírez-Bribiesca, and J. Tórtora-Pérez, "The relationship between fetal and maternal selenium concentrations in sheep and goats," Small Ruminant Research, vol. 73, pp. 174-180, 2007.

[18] C. Aceves, J. A. Ruiz, C. Romero, and R. C. Valverde, "Homeorhesis during early lactation. Euthyroid sick-like syndrome in lactating cows," Acta Endocrinologica, vol. 110, no. 4, pp. 505509, 1985.

[19] J. E. Ramírez-Bribiesca, J. L. Tórtora, M. Huerta, A. Aguirre, and L. M. Hernández, "Diagnosis of selenium status in grazing dairy goats on the Mexican plateau," Small Ruminant Research, vol. 41, no. 1, pp. 81-85, 2001.

[20] H. D. Stowe, J. W. Thomas, T. Johnson, J. V. Marteniuk, D. A. Morrow, and D. E. Ullrey, "Responses of dairy cattle to longterm and short-term supplementation with oral selenium and vitamin E1," Journal of Dairy Science, vol. 71, no. 7, pp. 1830-1839, 1988.

[21] J. E. Rowntree, G. M. Hill, D. R. Hawkins et al., "Effect of Se on selenoprotein activity and thyroid hormone metabolism in beef and dairy cows and calves," Journal of Animal Science, vol. 82, no. 10, pp. 2995-3005, 2004.

[22] H. Martínez-Salgado, R. Castañeda-Limones, D. LechugaMartín del Campo et al., "Deficiencia de yodo y otros posibles bociógenos en la persistencia del bocio endémico en México," Gaceta Médica de México, vol. 138, pp. 149-156, 2002.

[23] M. Vela-Amieva, C. Hernández-Osorio, S. Gamboa-Cardiel, C. R. González-Contreras, M. E. Pérez-Andrade, and J. OrtizCortés, "Hipertirotropinemia en recién nacidos mexicanos," Salud Pública de México, vol. 45, pp. 269-275, 2003.

[24] D. Behne and A. Kyriakopoulos, "Mammalian seleniumcontaining proteins," Annual Review of Nutrition, vol. 21, pp. 453-473, 2001.
[25] D. M. Driscoll and P. R. Copeland, "Mechanism and regulation of selenoprotein synthesis," Annual Review of Nutrition, vol. 23, pp. 17-40, 2003.

[26] A. D. Sheppard, L. Blom, and A. B. Grant, "Levels of selenium in blood and tissues associated with some selenium deficiency diseases in New Zealand sheep," The New Zealand Veterinary Journal, vol. 32, pp. 91-95, 1984.

[27] G. E. Carstens, P. M. Mostyn, M. A. Lammoglia, R. C. Vann, R. C. Apter, and R. D. Randel, "Genotypic effects on norepinephrine-induced changes in thermogenesis, metabolic hormones, and metabolites in newborn calves," Journal of Animal Science, vol. 75, no. 7, pp. 1746-1755, 1997.

[28] A. J. Vidal-Puig, C. D. Grujic, C. Y. Zhang et al., "Energy metabolism in uncoupling protein 3 gene knockout mice," Journal of Biological Chemistry, vol. 275, no. 21, pp. 16258-16266, 2000.

[29] G. Kelly, "Peripheral metabolism of thyroid hormones: a review," Alternative Medicine Review, vol. 5, no. 4, pp. 306-333, 2000.

[30] R. J. van Saun, T. H. Herdt, and H. D. Stowe, "Maternal and fetal selenium concentrations and their interrelationships in dairy cattle," Journal of Nutrition, vol. 119, no. 8, pp. 1128-1137, 1989.

[31] A. E. Hefnawy, R. López-Arellano, A. Revilla-Vázquez, E. Ramírez-Bribiesca, and J. Tórtora-Pérez, "Effect of pre- and postpartum selenium supplementation in sheep," Journal of Animal and Veterinary Advances, vol. 7, pp. 61-67, 2008.

[32] W. A. Head, P. G. Hatfield, D. M. Hallford, J. A. Fitzgerald, M. K. Petersen, and J. N. Stellflug, "Effect of selection for lifetime production of lamb weaned on hormonal factors that affect growth in targhee ewes and lambs," Journal of Animal Science, vol. 74, no. 9, pp. 2152-2157, 1996.

[33] B. Contempré, J. F. Denef, J. E. Dumont, and M. C. Many, "Selenium deficiency aggravates the necrotizing effects of a high iodide dose in iodine deficient rats," Endocrinology, vol. 132, no. 4, pp. 1866-1868, 1993.

[34] D. A. Fisher, "Thyroid system ontogeny in the sheep: a model for precocial mammalian species," Advances in Experimental Medicine and Biology, vol. 299, pp. 11-26, 1991.

[35] S.-Y. Wu, D. H. Polk, W. S. Huang, W. L. Green, B. Thai, and D. A. Fisher, "Fetal-to-maternal transfer of thyroid hormone metabolites in late gestation in sheep," Pediatric Research, vol. 59, no. 1, pp. 102-106, 2006. 

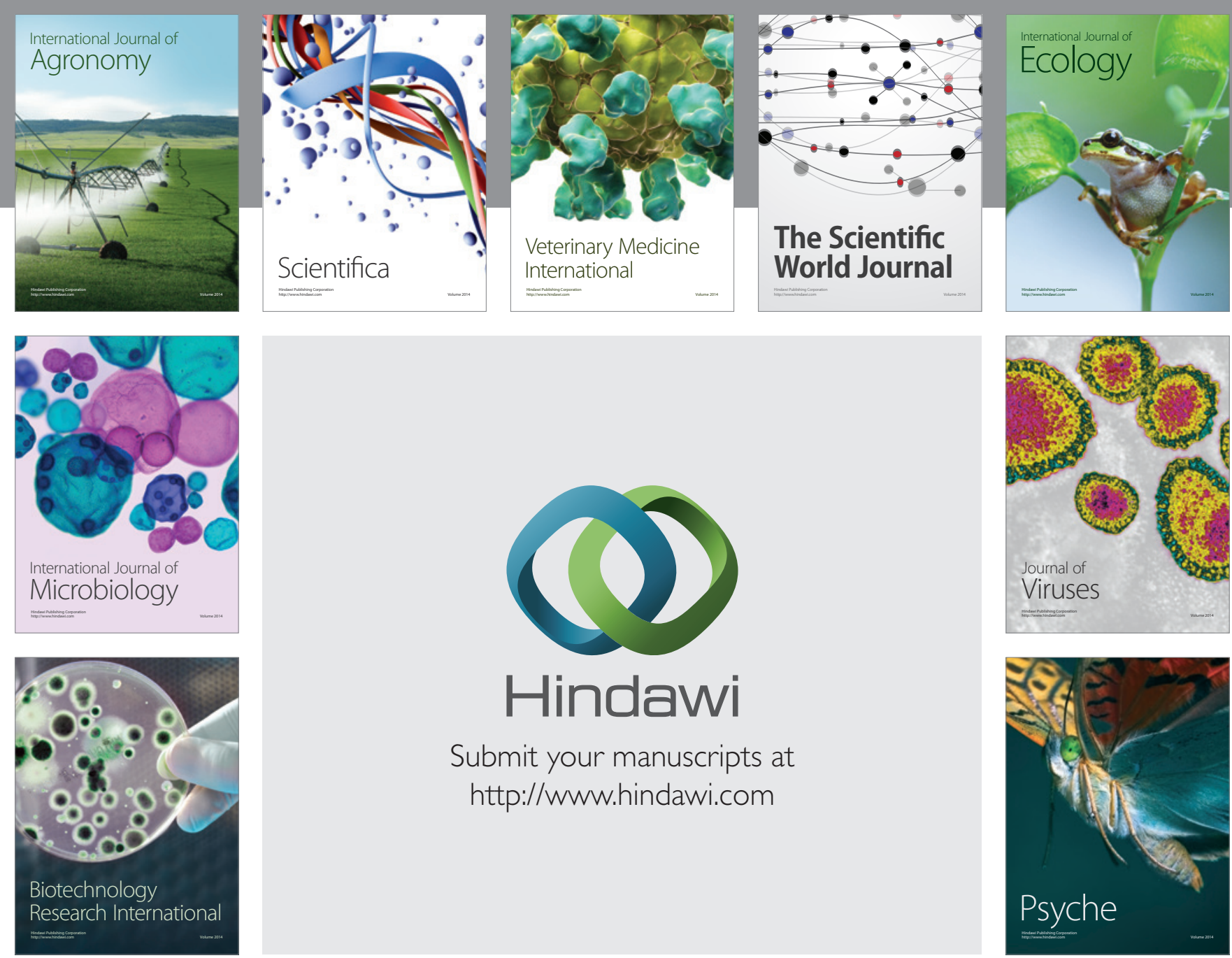

Submit your manuscripts at http://www.hindawi.com
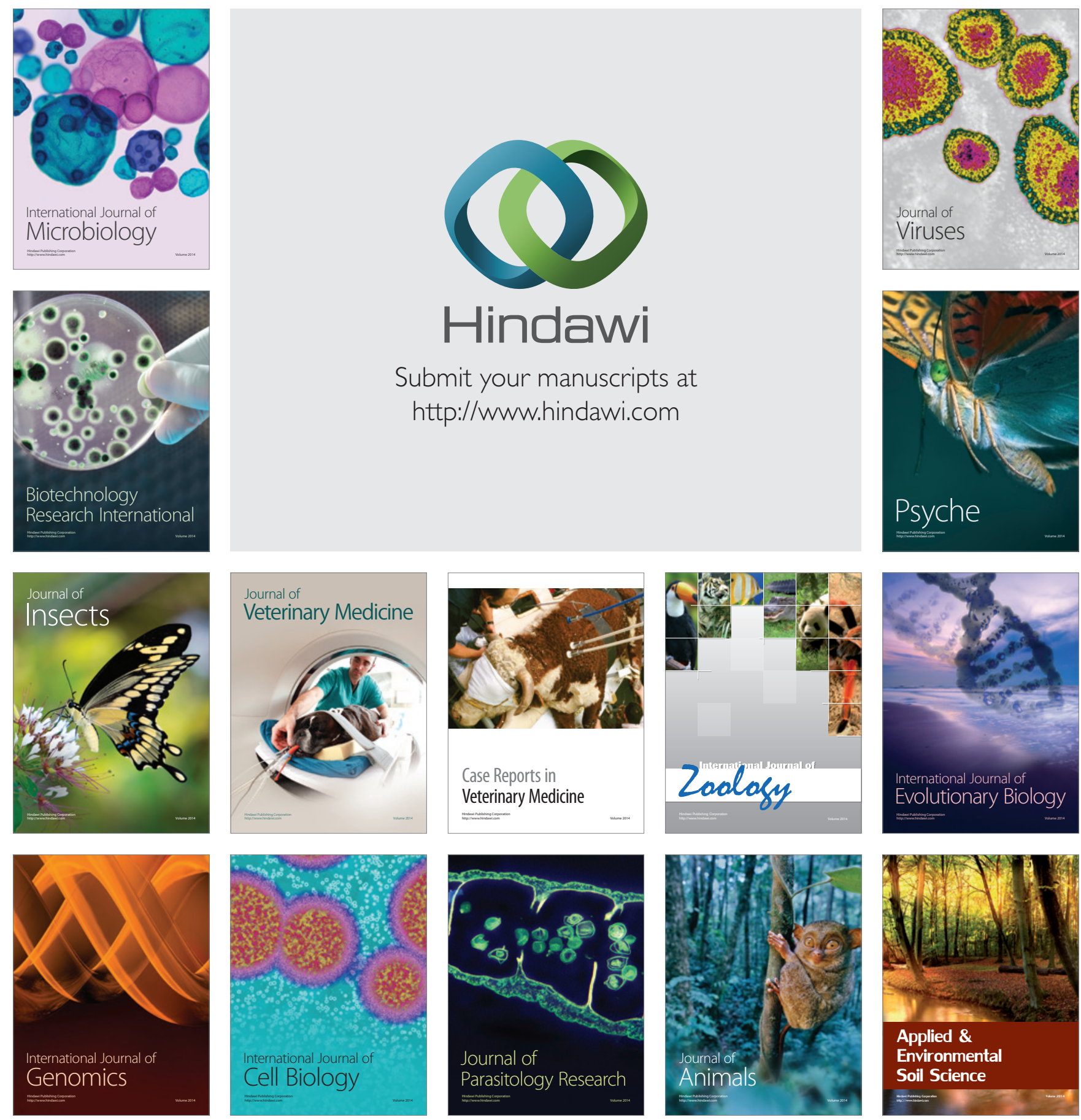